\title{
Straddling Two Continents: Social Policy and Welfare Politics in Turkey
}

\section{Ayse Idil Aybars and Dimitris Tsarouhas}

\begin{abstract}
There has been an increasing academic interest in understanding the dynamics of social policy in the Middle East and developing a conceptual 'model' to account for the particular characteristics of welfare arrangements in the countries of the region. While part of this framework, Turkey represents an exceptional case due to the Europeanization processes the country is undergoing in various policy areas, including social policy. The influence of the European Union on the shape of Turkish social policy, as illustrated by the government's recent reforms in the labour market and social security domains, is hereby used to outline the position of Turkey vis-à-vis both the Southern European welfare regime and the Middle Eastern pattern. This article seeks to assess the dynamics of Turkish social policy in light of the country's political, and socio-economic dynamics, as well as the external influence exerted by the EU and international financial institutions. The aim is to examine Turkish welfare arrangements in a comparative manner and consider its suitability with reference to either of the two models. Looking at major trends in social security and the labour market, the article argues for a Turkish 'hybrid' model embodying the characteristics of both. Subject to EU explicit pressures for reform absent elsewhere in the Middle East, the data nevertheless show that Turkey has yet to make the qualitative leap forward that could place it firmly within the Southern European welfare group.
\end{abstract}

\section{Keywords}

Turkey; Middle East; Social policy; Welfare models

\section{Introduction}

The field for comparative welfare state analysis has been flourishing since Esping-Andersen's path-breaking work on the Three Worlds of Welfare Capitalism (I990). While research interest has for long focused on the industrialized Western world, there has been increasing academic attention on social policies in developing countries in an attempt to build up explanatory models

Address for correspondence: Dimitris Tsarouhas, Bilkent University, o68oo Bilkent-Ankara, Turkey.Email: dimitris@bilkent.edu.tr 
broadening the grounds for comparative analyses. 'Modelling' mainly aimed at explaining the different trajectories of welfare followed in Latin America, East/South-east Asia, and Central and Eastern Europe, among others. Within this framework, scholarly interest in understanding the dynamics of welfare and social policy in the Middle East has recently increased, although it is still in need of expansion to develop a comprehensive understanding to account for the specificities of welfare states in the region.

The latter seems a challenging task as countries in the Middle East are far from displaying systematic similarities in their economic resources, political structures, legal frameworks and cultural and historical trajectories. However, this does not mean that the possibility of identifying common features to these countries' social provisions, common threads to the orientation of their social policies and common denominators to outline the specificities of the region's welfare states is ruled out. A detailed examination shows that Middle Eastern countries share a number of common characteristics, mostly region-specific.

Part of the geographic Middle East and sharing historical, political and cultural traits with other states in the region, Turkey is part of this framework. Nevertheless, it represents an exceptional case particularly with respect to the Europeanization processes the country is undergoing in a variety of policy fields, including social policy. The influence of the European Union on the shape of Turkish social policy, as illustrated by the government's recent labour market and social security reforms, is mostly debated with reference to the commonalities that Turkey shares with the countries exemplifying the 'South European' welfare regime.

This article aims to assess the dynamics of Turkish social policy in light of the country's political, economic and social dynamics, as well as the external influence exerted by the EU and international financial institutions (IFIs). Our aim is to examine Turkish welfare arrangements in a comparative manner. Looking at major trends in social security and labour market arrangements, it is argued that Turkey represents a 'hybrid' model embodying the characteristics of both Middle Eastern and South European welfare models. The data presented here show that, although Turkey's dynamics are distinguishable from those elsewhere in the region due to the effects of its EU membership bid, important labour market indicators set it apart from the South European model too.

\section{Social Policy in the Middle East}

Recent studies have outlined the main features of social policy in the Middle East, on the basis of policy processes and contents, on the one hand, and objectives and ideas of social policy on the other (Bayat 2002; Karshenas and Moghadam 2006; Jawad 2008). A commonly shared characteristic in the Middle East ${ }^{1}$ is that all countries departed from a very low development base in the aftermath of the Second World War. The main development indicators, such as infant mortality (300 per I, ooo live births in I96o), life expectancy (50 years in I960) and adult illiteracy (65 per cent in I970) remained way behind equivalent standards in the developed world, but also compared to other developing countries outside the region with similar per capita income levels 
(Karshenas and Moghadam 2006). This started to change in the I970s, particularly for those countries profiting from increasing oil revenues, but also in countries like Turkey, which saw rapid rates of urbanization, structural changes in the economy and agrarian reform. Middle Eastern states caught up with other developing countries with similar per capita income levels on indicators like general health and education, particularly for the young generations. Nevertheless, most countries in the region still rank lower on the Human Development Index (HDI) than their per capita income levels (Henry and Springborg 200I).

While the character of state social policy has been typically labelled as 'residual' in these countries (Jawad 2008), starting from the late ig6os/early I970s period, an increase in public social expenditure levels is observed, particularly in health and education, although to varying extents and at different rates. Notwithstanding real progress in literacy rates and higher levels of public spending in health and education, education remains the area with the most acute problems, where a wide gap between the Middle East and other regions with similar per capita income levels exists (Karshenas and Moghadam 2006). This is particularly true when one looks at high illiteracy levels and low quality of education (i.e. mean years of schooling, enrolment figures for secondary and tertiary education, and gender gaps throughout the whole education cycle), which are also reflected in the Turkish case, despite recent improvements.

The gender gap in educational attainment is remarkable in almost all Middle Eastern countries and is much higher than equivalent gaps in countries with comparable per capita income levels. The low starting point for the Middle East should be factored in here. ${ }^{2}$ This is also reflected in the very low female labour force participation rates in these countries, which have nevertheless started to increase over the past decade. High fertility and rapid population growth are other, closely related, factors behind the gender gap. On the other hand, the average fertility rate in the region was 7.2 in Ig6o but had declined to 3.I by 2002 (Karshenas and Moghadam 2006). A crucial explanation reinforcing the gender gap in the Middle East is the traditional patriarchal family structures and the central role attached to the family as the main provider of welfare services.

In terms of employment, and in addition to the increasing trend of female labour force participation, it is possible to identify common trends shared in the region. The high rate of unemployment, currently among the highest in the world and on the rise since the ig8os, is one of them. Worryingly, the unemployment trend is highest among the educated youth and women. This is explained by the lack of a skilled labour force since the Ig6os, which is essential for international competitiveness and economic diversification. Considering the very high youth cohort of the Arab countries and the explosive effects of youth unemployment (Chaaban 2009), this is an issue of high salience. Another important factor in this respect concerns 'the limitations of the labour market-related social welfare policies pursued by governments in the region' (Karshenas and Moghadam 2006: I4). While these countries provided a range of benefits to workers in government and corporate sectors up to and just after the oil-boom era, these benefits were strongly attached to 
these jobs or job-holders' privileges. Even today, in most countries unemployment benefits and social insurance are not available to new labour market entrants.

The gender dimension of social policies in the Middle East has been conceptualized in relation to the 'neopatriarchal' nature of the state, upholding 'a gender ideology, a set of cultural norms, and a social relationship predicated on the male breadwinner/female homemaker role' (Moghadam 2006: 223). Social policies are highly gendered, and 'female disadvantage continued to be a hallmark of the . . . region well into the Ig9os' (Karshenas and Moghadam 2006: I8). This is mainly discussed in relation to Muslim family law, shared by most countries in the region. While Turkey has pursued significant secularizing reforms in terms of civil and political rights, including family law, the persistence of patriarchal relations and traditional division of labour between the sexes is still evident.

Clientelism is another important shared characteristic, as the main beneficiaries of social policy have been groups with access to state power. This has been combined with distributive populism according to which the state entered an agreement with the lower and middle classes to provide basic necessities in return for social peace. Despite the practical difficulties of holding to such a deal in the neo-liberal era, many people in most Middle Eastern countries still 'tend to look at the state as their main source of protection as well as misfortune' (Bayat 2002: 9).

Most importantly for the purposes of the present article, public policy in these countries has traditionally been economic-oriented, and the social dimension has been accorded a secondary status (Jawad 2008). Social policies and welfare states, to the extent that they were available, followed the path of nation-building, state-building and developmentalist objectives, rather than being built on the idea of social citizenship rights, as was the case in Western Europe. Introducing social policies was more about ensuring 'a social base of support for the emerging nation-states or regimes, than [about] any concept of citizen rights' (Karshenas and Moghadam 2006: 4). Populist redistributive measures, mainly privileging government employees, were a means of nationbuilding, state formation and consolidation, as well as regime legitimization (Schlumberger 2000). The concern with regime legitimization has also led to the politicization of social policies and resulted in the instrumental use of social policies 'by the state to gain power and political legitimacy' Jawad 2008: 27I).

Another important ideological factor behind social policies common to the region is the influence of religion on social policy. As the dominant religion in the Middle East, Islam is said to bear an important cultural influence, particularly on wealth and gender inequalities (Kuran 2004). In consequence, the consideration of religious and cultural forces, as well as social movements, becomes crucial in understanding social policy in the Middle East (Clark 2004; Jawad 2008: 276).

A final, but no less important contextual point on social policy in the Middle East is that it has been largely prone to external intervention (Henry and Springborg 200I), 'opening up to the European-dominated economy since the I7th century through colonization and mandate rule . . and since 
the I980s, economic reform under the pressure of globalization and structural adjustment programmes' led by institutions such as the IMF and the World Bank (Jawad 2008: 270). It is mainly under their influence that the countries of the region have undertaken privatization and marketization reforms over the last decades, further limiting the role of the state in welfare provision and as a public sector employer.

Jawad (2008) sums up the main factors behind the state's limited role in the region as: (I) the misallocation of resources and the prioritization of military spending over key social sectors; (2) the narrow economic focus of public policy; (3) the dominance of minority factions dating back to the colonial era; (4) political insecurity and military conflict; (5) high levels of state indebtedness; and (6) the introduction of structural adjustment programmes and the increasing privatization programmes. These elements combine to produce inequalities and structural unemployment. Most of these factors pertain equally to the case of Turkey and become important in any attempt to classify the Turkish welfare state.

Where does Turkey stand in this picture? It is not surprising that most of the points outlined are, or have been until very recently, the underlying features of Turkish social policies. The starting point of welfare policies in Turkey also had to do with considerations of nation-building and development, driven by populist economic and social policies (Boratav and Ozugurlu 2006). This is a fundamental point distinguishing the Turkish welfare state from its European counterparts. What distinguishes Turkish social policy from its Middle Eastern counterparts, however, is its close relationship with the EU, which culminated in the acceptance of the country as an official candidate in I999, followed by the opening of accession negotiations in 2005 . The direct and explicit influence of the EU, absent from the other countries in the region, has resulted in major social policy reform initiatives over the past decade. Although future predictions are by default precarious, the endpoint of this process may well be Turkey's eventual inclusion in the South European welfare model. The data discussed and analysed below, however, reveal that the country has yet a long road to travel in that direction, provided that this is indeed the direction its policy-makers have chosen.

\section{Social Policy in Turkey: Political and Economic Context}

The creation of the Turkish Republic in I923 found the country in economic and social disarray. After a decade of war mobilization the country was poor, worn out and with its commercial and financial elites outside the borders of the new country. The ruling elite under the leadership of Mustafa Kemal Atatürk embarked on a large-scale project of modernization through nationbuilding and the pursuit of developmentalist objectives. In the early years of the Republic, economic growth and the relief of an exhausted population were an urgent priority. Political and economic decisions during the one-party era (I923-45) had a lasting effect on social policy arrangements.

In I924 a new Constitution was proclaimed in line with the nationalist project of Atatürk and his drive for the country's rapid westernization. Importing legal expertise from Europe, the regime set the foundation stone for 
the future development of social rights through the introduction of the concept of citizenship (Boratav and Ozugurlu 2006). Turkey's modernization drive - including far-reaching reforms of the alphabet and the dress code, as well as law - went hand in hand with an attempt to consolidate and legitimize the new regime through high rates of growth. The historically diverse pattern of social policy development was visible from the early Republican era. Class conflict and the formation of an industrial working class gave birth to Europe's welfare state in the nineteenth century; in Turkey the concept of class differences was rejected by Atatürk.

The first significant piece of legislation on labour issues, the 1936 Labour Law, prohibited the formation of trade unions as well as strikes and lockouts. Labour conflicts were to be resolved through compulsory arbitration. On the other hand, the same law established the principles, types and branches of the social insurance funds that would start operating in the postwar era (Dilik I985), while separate legislation was passed for the retirement funds of employees in state economic enterprises in 1938 and I942, respectively. Also, legal novelties regarding a day's rest and prohibiting more than six days' work were introduced, as Turkey joined the ILO in I932. Nevertheless, social security initiatives were of a selective and fragmented nature that provided coverage for a core of large firm employees and left most of the population, predominantly agrarian at that time, outside any form of coverage (Boratav and Ozugurlu 2006).

The one-party regime paved the way for the eventual institutionalization of Turkey's social policy regime. It realized that population moves and the heavy legacy of war had made self-help systems and charitable help through family networks, the then dominant features of social assistance, inadequate. In fact, the administrative/rationalist social policy initiatives of the time were in line with the western-inspired approach that Ataturk sought to introduce. There is thus little coincidence in the fact that, as elsewhere in the Middle East, a top-down approach to social policy was implemented, with social and employment rights resulting from government fiat rather than societal demand. Some of the benefits of this approach manifested themselves later: free education at secularized state schools gradually transformed a country whose literacy rate was around io per cent in I923. On the other hand, the state paternalist approach towards the people inherited from the Ottomans was maintained. Until today, the concept of the state as the father of the nation retains more than symbolic value.

Based inter alia on the principle of populism as a constitutive element of the new state, the Republic's early years were marked by attempts to reach economic autarky through the encouragement of public economic enterprises, five-year development plans and support to import-substitution policies (Ozbudun ig80).

The single party-rule era from I923 until I946 entails a paradox. That era is distinguished by the monopolization of power by the Republican People's Party officials in alliance with large landowners in the provinces and to the detriment of slowly emerging social forces, such as the commercial middle class or medium-sized farmers. But it is due to the policies of that era, and in particular the setting up of a communications network to cover the whole 
country and the support of state-controlled and regulated entrepreneurial undertakings, that those excluded from political power became conscious of their exclusion and successfully gained power in the multi-party period.

During the Democrat Party (DP) period in office (I950-60) socio-economic inequalities rose mainly as a result of rampant inflation that penalized fixed-income earners despite rising wages. Farmer support through massive subsidies encouraged populism, which became a constant feature of Turkey's politics and contributed to severe economic downturns after the I970s. It was in the latter decade that the end of the boom years led to rising social tension, the disintegration of the two-party system and the eventual military coup in I980.

In the early years of the multi-party era the ban on class-based associations was lifted and collective bargaining was allowed. The 1947 law on trade unions permitted a (restricted) functioning of trade unions (Boratav and Ozugurlu 2006).

However, the authoritarian inclinations of the DP governments led to a military intervention by a junta composed of medium-ranking officers in I96o. A year later, the ig6i Constitution was proclaimed and its social policy content bore the marks of progressive thinking. Turkey was said to be a 'social [welfare] state' (Article 2) and workers' rights in the workplace were asserted (unionization, collective bargaining, the right to strike and paid leave) as well as welfare rights on social security, education and housing (Articles 44-50). As Ozbudun (I980) notes, what is remarkable about these comprehensive social policy guarantees is the absence of a corresponding constituency that demanded them as a matter of social right.

National planning and national industrialization were to continue. In the soft economic environment of the time marked by extensive protection for national capital, this period was accompanied by relative social harmony. The I96I wording of the Constitution reflects a deep penetration of Western ideas regarding the universal character of welfare protection and the securing of minimum social rights. What is more, the I96os is the decade in which equity issues gain a mainstream place in the public debate, illustrated by the rise of socialist tendencies in the growing trade union movement (Ozbudun I980).

In practice, formal social policy remained limited to the provision of stateprovided free education and a combined public health and pension system associated with employment status (Bugra and Keyder 2006). Two social security organizations, one for wage earners (Sosyal Sigortalar Kurumu, SSK) and one for the civil servants and military personnel (Emekli Sandiği, ES) became operational in the second half of the I940s. In I97 I a third fund was introduced for the self-employed (Bağ-Kur, BK) and these insurance funds dominated the social security landscape until recently, with a marginal contribution from the state. In a country with a rampant unregistered economy and a large agricultural sector, the social insurance system offered privileged social security services to ES beneficiaries, but excluded a large percentage of the population from coverage.

To contain social tension resulting from poverty and in the absence of compensatory transfers in case of unemployment, informal mechanisms of relief centred on the family have been used. These have operated in tandem 
with clientelistic practices on the part of state authorities. Housing provides an example (Bugra I998), with overnight-built squatter houses (gecekondu) on the outskirts of major urban centres. Operating on the basis of a patron-client relationship, such housing has periodically met with the approval of state authorities and has contributed, inter alia, to the gradual integration of rural migrants to urban centres, in addition to providing immediate relief to lowincome groups.

Health services increased in the postwar period and especially after the I96I military intervention. The Integrated Health Services Scheme, operational from ig6o until the ig8o coup, sought to universalize access to health coverage and the relevant law on the Nationalization of Health Care Delivery (Law 224) is indicative of the statist and universal orientation of the I96r intervention (Agartan 2005). In the I950s new hospitals were built and the mandate of the Health Ministry increased to include curative services. Even in this period, however, the private sector retained a strong role in health-care provision.

\section{Recent Reforms and Contemporary Challenges}

The post-I980 period in Turkish social policy is marked by a shift from an inward-looking economic regime to outward-looking, market-oriented policies and the prevalence of a neo-liberal agenda driven by financial liberalization (Bugra and Keyder 2006; Boratav and Ozugurlu 2006). It is a period of instability, short-lived coalition governments endorsing populism and recurring cycles of economic volatility. The Ig8o coup was followed in 1982 by a new Constitution, still in force and more regressive than the ig6r one in terms of its social policy content, identifying strict membership conditions for trade unions, restricting strikes and banning the political involvement of trade unions.

This period is also characterized by a series of economic crises in the face of internal and external fluctuations leading to macro-economic instability, reinforced by large public deficits and persistently high inflation (Yakut-Cakar 2007). The numerous economic imbalances, moreover, were always followed by 'standby agreements' with the IMF and the structural adjustment programmes of the World Bank. Apart from sustaining budgetary discipline, these institutions have been very influential in co-shaping recent health and pension reforms, as well as social assistance programmes.

Another major influence in the recent reforms in the social domain is certainly entailed in Turkey's long and uneasy relationship with the EU, which culminated in the recognition of its candidacy status in I999 and the start of accession negotiations in 2005. Although it has been argued that the impact of the EU on the social domain has not been significant compared to those of the IMF and World Bank (Yakut-Cakar 2007), recent labour market initiatives can be traced to the EU accession process. The section below outlines the reform process Turkey has been undergoing since the late I9gos in two key domains, the social security system and the labour market, in line with the influence of the IMF and World Bank for the former, and of the EU for the latter. In the face of external and internal pressures outlined above, most of these reforms have been undertaken by the Justice and Development 
Party (AKP) government, which has been in power since 2002 based on 'an amalgam of neo-liberalism with social conservatism' for social policies based on moderate Islamic values (Bugra and Keyder 2006: 213).

\section{Social security}

The reform of the social security system has mainly sought to cope with the unsustainable character of the existing system. Similar to many other countries, the debate has centred on fiscal constraints stemming from the high ratio of pension recipients to active contributors, the balance to be established between the state and the market in pension provision, and the necessity for universal coverage. Most significantly in the Turkish case, the need for reform has arisen from 'a lack of compatibility between the corporatist character of the formal social security system and the current structure of the labour market', which is characterized by a very high incidence of informal employment and very low levels of female participation ${ }^{3}$ (Bugra and Keyder 2006: $2 \mathrm{I} 6)$.

While the imbalances of the social security system had for a long time made reform necessary, major structural reform was introduced in I999 under the guidance of the World Bank, and foresaw a two-stage process, based on short-term measures and a longer-term perspective on the transformation of administrative structures and the establishment of a new system. The first stage of the reform saw the introduction of increases in both the minimum retirement age and the minimum contribution period. The second stage aimed to sustain initial changes and build a stronger system in the long run, starting with a series of reform proposals in 2004. These included administrative reforms based on four pillars: the establishment of universal health insurance, the restructuring of social assistance and services, the reform of pensions, and the foundation of an institutional structure to harmonize the other three pillars (Yakut-Cakar 2007). For this latter purpose, the Social Security Institution was established in 2006. The subsequent reforms concerning pensions aimed mainly to establish a single pension system, and entailed the gradual increase of the retirement age to reach 68 years for both men and women in 2075 .

The reform of the health-care system follows similar lines. Health benefits have long been tied to employment status, leading to important differences of coverage and quality among three different institutions. A Green Card programme, established in I992 for poor and uninsured people, sought to provide free access to doctors and hospitals within the social security system so as to gradually reach universal coverage. Still, it is estimated that more than onethird of the population is not covered by health insurance and have to pay for their needs themselves (World Bank 2005). On the other hand, state expenditure on health, despite its insufficient coverage levels, has been rising in line with global trends, which is another important factor behind the reform process driven by the World Bank in Turkey. ${ }^{4}$ The debate over the reform again centres on the institution of a single health insurance agency to provide a minimum package of health services on a universal basis, regardless of employment status. This will be financed by the contributions paid by those 
who are earning above the poverty line. Along with this, the reform also encourages private health insurance and private provision of health services, as well as the decentralization of the Ministry of Health and the autonomous management of hospitals in the long run (Bugra and Keyder 2006; YakutCakar 2007).

The most important aspect of the social security reform concerns the unification of the existing social security organizations under the Ministry of Labour and Social Security (MLSS). This is an important step as the current fragmented structure is largely inefficient. When it comes to the pension system, the reform process has mainly affected those who are formally employed, and offered no comprehensive remedies to the informally employed, which constitute almost half of the total labour force (Yakut-Cakar 2007). Criticism raised against the reform has thus described the changes as signalling a move towards 'the marketization of services and encouragement for the private sector to collaborate in a public-private mix of service provision', which will deepen persistent inequalities within the system (Boratav and Ozugurlu 2006; Yakut-Cakar 2007: I24).

\section{Labour market}

There has been a significant decline in formal employment opportunities in Turkey in the post-I98o period in line with the move towards an outwardlooking, market-oriented economic strategy. This process implied the deregulation and flexibilization of the labour market and an extensive privatization process, which, coupled with subsequent economic crises, resulted in a sharp decline in formal employment (Bugra and Keyder 2006; Boratav and Ozugurlu 2006). In this respect, the most significant problems of the Turkish labour market, along with the large share of informal jobs, concern increasing long-term unemployment levels and the low employment rates among disadvantaged groups, including women, young people, people with disabilities and the unskilled (Glynos et al. 2008).

These factors have been signalling the need for reform in order to adjust the Turkish labour market to changing conditions as well as to EU standards. One of the most important attempts in this respect has been the adoption of a new Labour Law (No. 4857) in 2003, mainly aiming to transpose relevant EU regulations into national legislation. The law contains provisions in a broad field of industrial relations, including non-standard employment, flexible working time, temporary employment relationships, the establishment of a Guarantee Fund providing protection for workers in the event of employer insolvency, transfer of undertakings, the employer's obligation to inform employees of the establishment of a tripartite Advisory Board, job security, and the effective implementation of occupational health and safety measures. At the same time, Turkey ratified the ILO Conventions concerning freedom of association.

However, the existing industrial relations framework is under continuous pressures for reform by EU authorities, who call for full trade union rights and an effective social dialogue mechanism (Glynos et al. 20o8; Commission of the European Communities 2009: 63). In this regard, initiatives have recently 
been taken in the area of active labour market policies, mainly targeting women and young people, but also persons with disabilities. Within the framework of the Instrument for Pre-accession Assistance (IPA), aiming to prepare candidate countries for EU membership, special emphasis has been placed on the development of human resources to improve policies and institutional capacity in the labour market and in the areas of education and vocational training. Strengthening social dialogue has also been of particular concern, leading to numerous projects and programmes. The effects of these activities will only be known in the long run, but the EU accession process has clearly provided a significant impetus for change.

\section{Turkish Social Policy and the Southern European Model}

Ferrera (I996) identified a 'Southern European' model of welfare for Spain, Italy, Portugal and Greece, which, to some extent and in certain respects, has also been used to explain the Turkish welfare regime by some scholars (see Gough I996; Saraceno 2002). Taking into account the historical/institutional legacy of Turkish social policy as well as its transformation since the I980s, how does Turkey relate to the Southern European model and to what extent does it conform to its main characteristics?

A short summary of the model includes relatively low levels of public social expenditure, reliance on the family for welfare provision and a strong male breadwinner model illustrated through low levels of female employment and a status-based allocation of welfare benefits. Service provision is fragmented and inconsistent. Patronage and clientelism play an important role in welfare distribution and result from the failure of establishing a Weberian type of public administration and the prominence of political parties as the main aggregators of societal interests. Fragmentation is made worse by the strong position of 'insider' groups defending overtly generous benefits.

Turkish welfare provision has undoubtedly a lot in common with this picture. First, the centrality of the family in welfare delivery and the reliance on it to make up for inadequate provision by state authorities is a pervasive theme of social arrangements (Bugra and Keyder 2006). Second, clientelistic practices in welfare delivery through patron-client relationships form a constant picture of public policy. The insider/outsider dichotomy of the Southern European labour market is strongly in evidence in Turkey too, a situation made worse by the rampant unregistered economy and the exclusionary effect this has on millions of uninsured employees. It is therefore little surprise that Gough (200I) has placed all four south European states in a 'rudimentary assistance' model along with Turkey.

Still, drawing the conclusion that Turkish social policy is part of the Southern European model would be premature. There remain significant qualitative differences between Southern Europe and Turkey on vital aspects of social policy. Although these differences are best illustrated through statistical data, their nature is of a qualitatively significant character.

To start with, Turkish social policy is 'smaller' compared to that of EU member states. Public expenditure in Turkey was recorded as I I per cent in 2009, compared to 23 to 30 per cent for Southern European countries (OECD 
200gb). Benefit payments by the state are negligible and almost non-existent in policy areas such as child benefit. The Turkish Statistical Agency reports I3 per cent of the Turkish population to be in receipt of a regular pension, 3 per cent receiving child benefit and 2 per cent unemployment benefit (Eurofound 2003). It could be argued that this is not all that significant: Southern European states have also traditionally spent little on such benefits. As Turkish social expenditure rises (figure I), it is likely that expenditure on such items will increase too. In fact, the social security and health-care reforms outlined above indicate that, in line with the government's priorities, a more targeted approach on social policy may be forthcoming.

Figure 2 shows that in the mid-Ig9os Turkish employment rates for men were not substantially different from those found in Southern Europe; in fact, until 1999 the Turkish rate surpassed that of the other four states only to drop later and keep up only with the Italian equivalent by 2007, the last year for which comparative statistics are available. A clear explanation is urbanization combined with statistical alchemy: while workers count as fully employed in the agricultural sector, they drop out of the labour market picture in an urban setting. Nonetheless, and as pointed out by Bugra and Keyder (2006), the issue is deeper than that and relates both to sky-high levels of unregistered employment and to high unemployment rates in metropolitan cities. According to the latest available data, the official unemployment rate in Turkey stands at I3.4 per cent and I6.2 per cent for urban areas but the real rate is probably much higher. Meanwhile, the labour force participation rate stands at 49 per cent compared to 65.9 per cent in the $\mathrm{EU}_{27}$ at the end of 2008 and 6I per cent for Southern Europe (Eurostat 2009).

The explanation for this discrepancy lies with female employment rates. Figure 3 indicates that, akin to male employment but in a more pronounced

Figure I

Turkish social expenditure, $1980-2002$

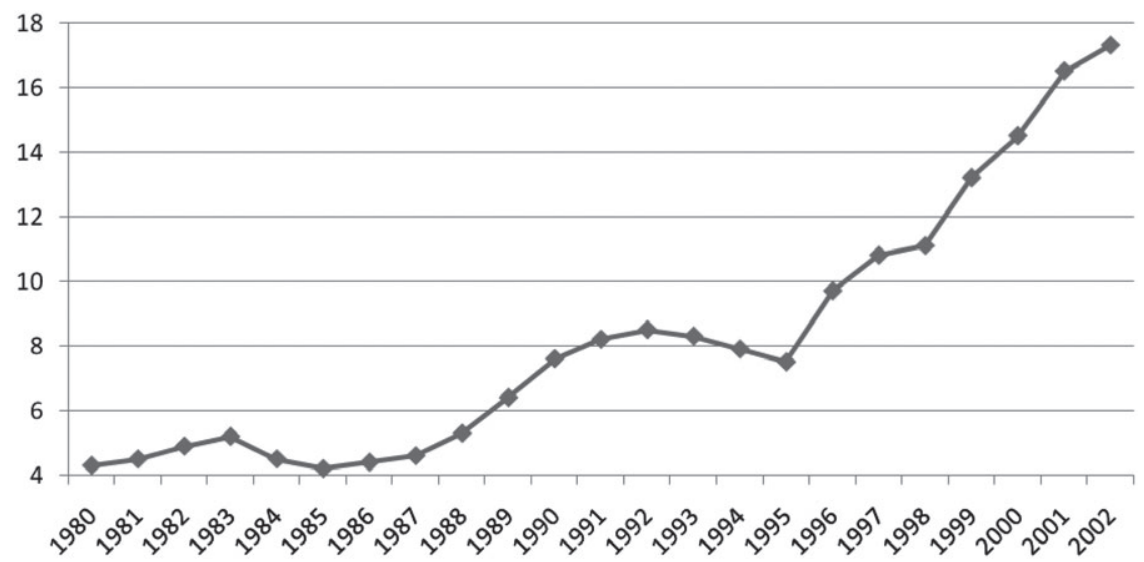

Source: OECD 2004 Social Expenditure Database. 
Figure 2

Male employment as a percentage of working-age people ( $\left.15^{-64}\right)$

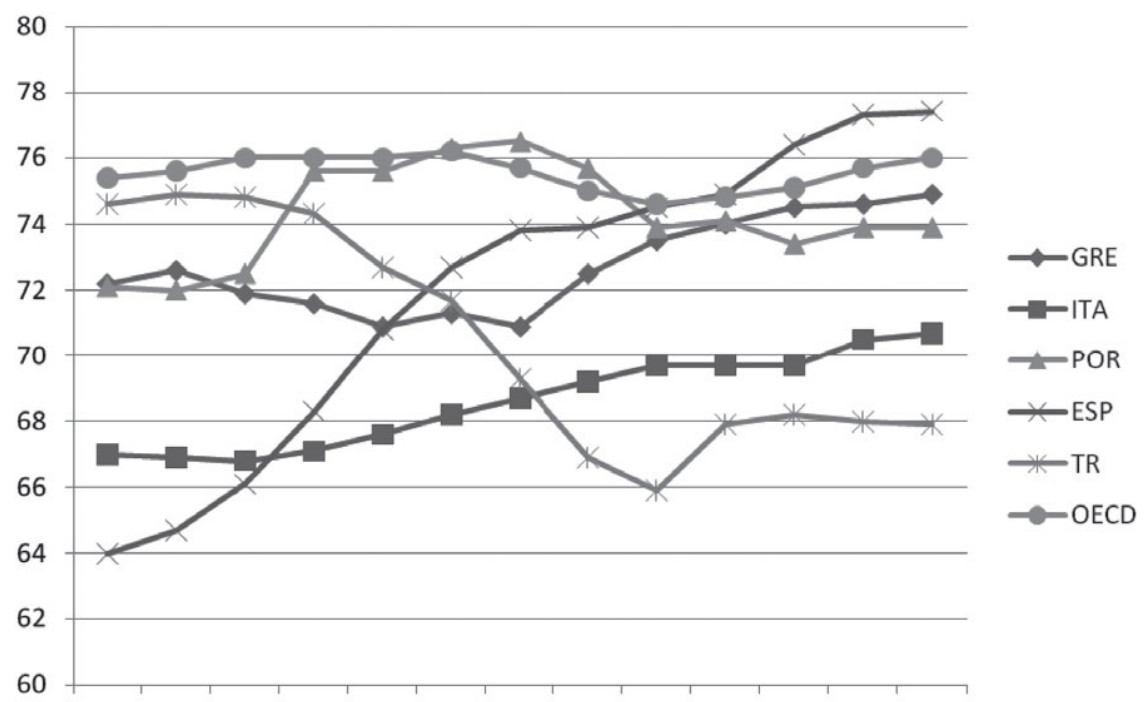

1995199619971998199920002001200220032004200520062007

Source: OECD (2009a).

fashion, the similar starting points of the mid-I99os became by 2007 an enormous discrepancy between Southern Europe and Turkey. While female employment rates have continuously risen in Southern Europe since the I99os, Turkish female employment rates have been in free fall, making the country an exception to the OECD rule. In Southern Europe, EU-motivated reforms - including the 2000 Lisbon strategy and its employment targets have led to an increase in employment boosted especially by higher levels of female participation in the labour market. The main factor behind falling rates of female labour force participation in Turkey has been the massive rural-urban migration since the Ig8os, which implies that women previously working in agriculture have recourse to informal jobs, or remain unemployed in cities due to lack of skills and education. On the other hand, male labour force participation rates have also been declining, which can again be explained by the same factor, but also points to the serious unemployment problem in the urban economy (Bugra and Keyder 2006).

Moreover, table I reveals that the discrepancy noted above is far from an outlier in an overall pattern of convergence. The table reflects the 2009 Human Development Report's findings and in particular one of its five main indicators, the Gender Empowerment Measure. The index is useful in that it is a measure of male-female inequalities within a country as well as a reflection of discrepancies in opportunities between the sexes. By including both 
Figure 3

Share of females of working age in employment, $1995^{-2007}$

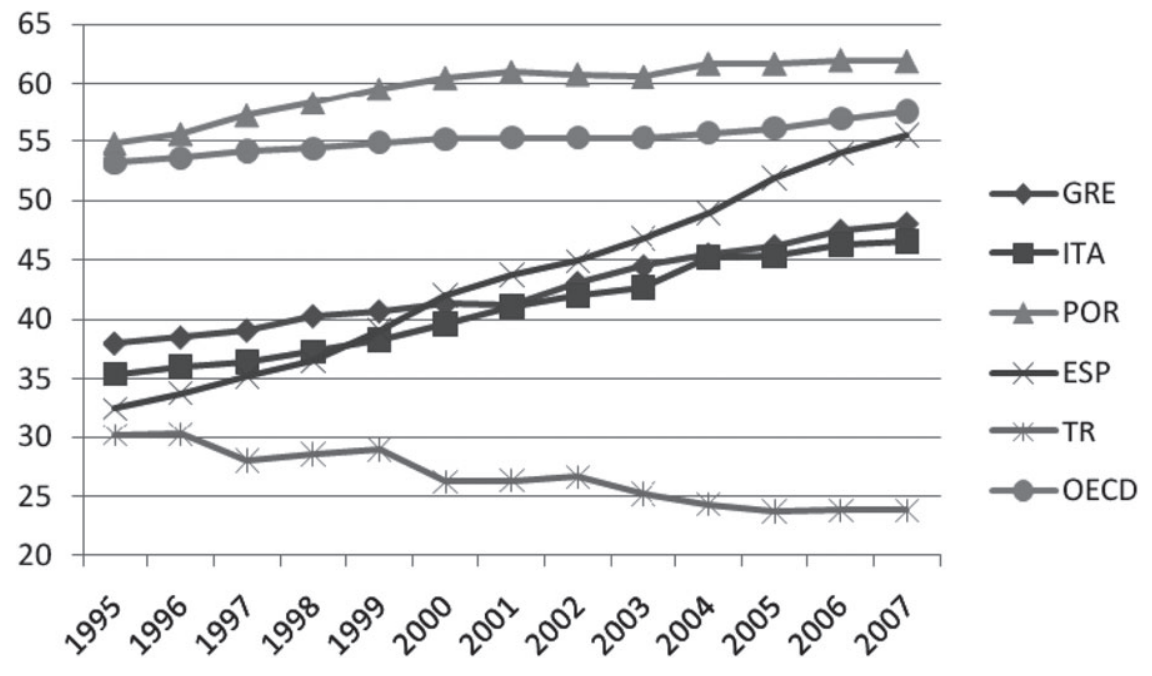

Source: OECD (2009a).

political and socio-economic variables, it offers a comprehensive picture of gender inequality. The data suggest that Turkey's gender issue is deeply entrenched in socio-economic and political life and does not reflect a temporary diversion from a pattern of convergence with Southern Europe. The low levels of female participation in political and economic life and women's unequal position to that of men closely approximates the situation in the Middle East. It also reveals a large gap between Turkey and even the most underperforming states in Southern Europe.

\section{Conclusion: In Between Different 'Models'}

Turkey's evolution has a lot in common with other Middle Eastern states. Prioritizing developmentalist objectives through its nation-building process, the young Republic of the I920s has gone a long way towards meeting those goals. By the early twenty-first century, the country has changed considerably. High GDP growth rates and rising education levels have narrowed some of the large gaps in education levels between men and women. Moreover, recent reform efforts point to an attempt to introduce a gender-neutral framework of social policy (Kilic 2008). Public health provision has improved considerably, leading to reduced infant mortality rates and higher life expectancy levels, co-existing with traditional patterns of informal welfare provision (Eurofound 2003). If the yardstick is the Middle East only, Turkey is among the class's best pupils. 
Sogial Policy \& Administration, Vol. 44, No. 6, December 2010

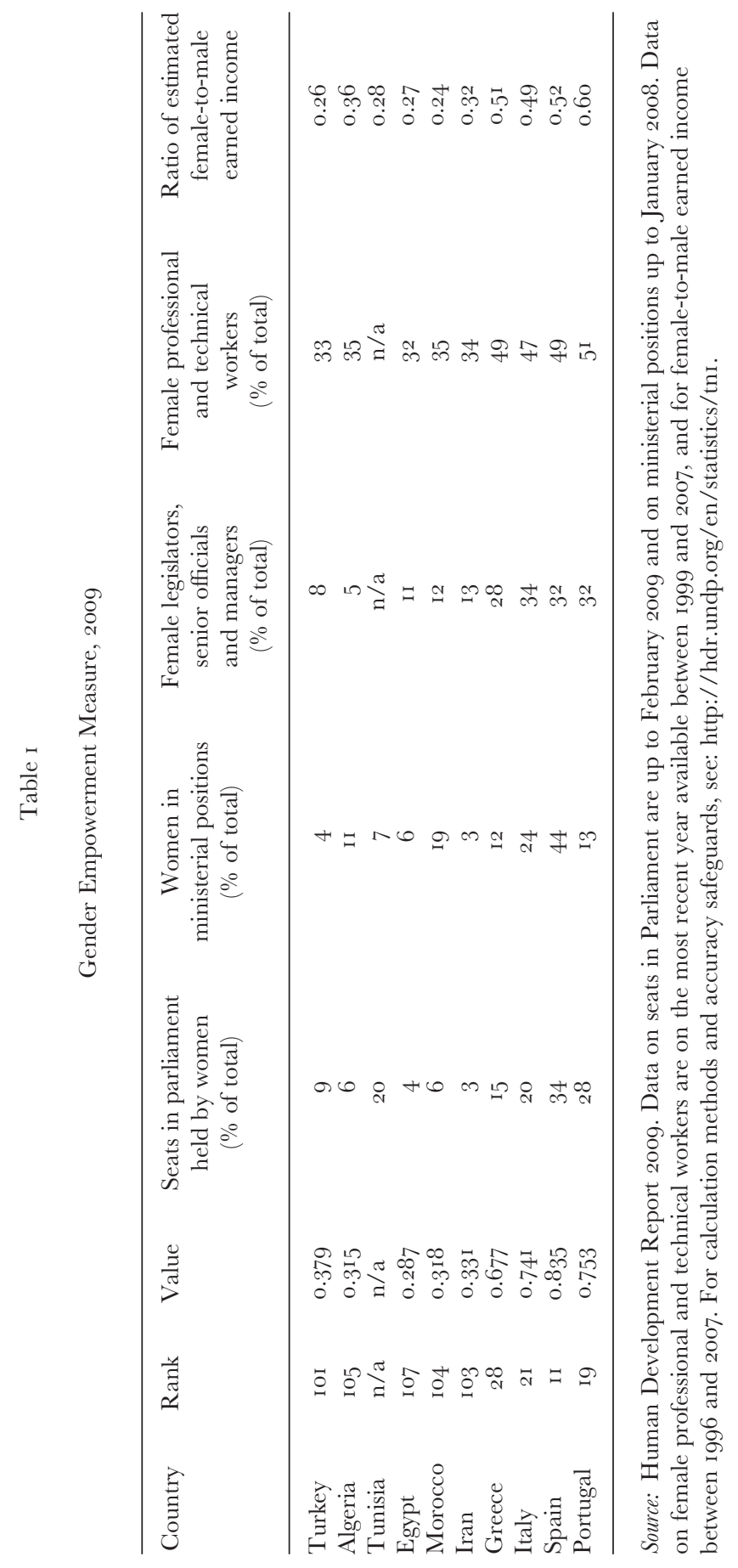


However, the external dimension in the design and implementation of Turkey's policies is not solely dependent on its relationship to the IFIs. Its ongoing EU membership negotiations, however turbulent and problematic (Tsarouhas et al. 2007), have a discernible effect on its socio-economic evolution. An earlier section has looked at some of those, but more are expected in the near future as the social policy and employment chapter of the EU body of law has yet to be opened between the two parties.

When compared to the Southern European welfare model, Turkey's distinctive position is clearly manifested. Its rising levels of social expenditure, its fragmented welfare provision system and the corporatist-based nature of its social insurance all hold true for Southern Europe too (Grütjen 2008). Nonetheless, in important policy areas, most notably labour market trends and gender divisions in employment, the country has yet to match the performance of other south European states. Also, education levels in Turkey are below EU standards and income differentials remain very high (Eurofound 2003). On the other hand, Turkey is a young country (29 per cent of the population under I5 years) which is getting better educated. If the pre-crisis growth rates are signals for future trends, declining emigration and a stabilizing population growth offer policy-makers the chance to make a qualitative leap forward in terms of economic and social indicators.

The picture painted above is mixed and points to the 'hybrid' character of the Turkish welfare regime, illustrating important features of both the Middle Eastern and Southern European welfare models, but remaining an outlier to both in certain respects. Lack of space and a long-overdue need to open Turkey's straddling welfare regime to academic debate restricted our focus to comparing the country with the archetypical examples of both models. Future research should also examine similarities and differences between Turkey and countries such as Cyprus, Malta and Israel, all of which exhibit 'hybrid' structures due to a set of historical, geographic and political factors and share common welfare features with Turkey, but neither of which have been comprehensively studied under any single specific welfare model.

Our examination shows that the Turkish welfare regime has been going through a significant transformation over the last couple of decades. While its starting point and early development was closer to its Middle Eastern counterparts, the influence of the EU and recent reforms in the social policy domain mark an inclination towards the Southern European cluster. Historical, cultural and institutional specificities of the country, however, are well reflected in this inclination, reiterating Turkey's well-known place straddling the two continents, also in the field of social policy.

\section{Acknowledgements}

The authors would like to thank Julia S. D'Connor and an anonymous referee for their helpful comments and suggestions. Thanks are also due to Burcin Turkmenoglu for his technical assistance. 


\section{Notes}

I. The countries mostly studied as part of the focus on social policy in the Middle East are Egypt, Tunisia, Algeria, Morocco and Iran.

2. In I970, female adult illiteracy rates in the region were about 79 per cent. By 200 , average levels fell to 23 per cent, compared to Io per cent in East Asia (Karshenas and Moghadam 2006: Io).

3. The latter gives rise to high rates of dependency, overburdening the health and pension systems.

4. Although the World Bank has long had health reform on its agenda, the most important factor behind its influence was the coincidence of its programme with the priority assigned by the AKP to the 'Transformation of Health' project in its 2002 party programme (Yakut-Cakar 2007).

\section{References}

Agartan, T. (2005), Health sector reform in Turkey: old policies new politics. Paper given at Young Researchers ESPANET Workshop, Bath, 3o June-2 July.

Bayat, A. (2002), Activism and social development in the Middle East, International Fournal of Middle East Studies, 34, I: I-28.

Boratav, K. and Ozugurlu, M. (2006), Social policies and distributional dynamics in Turkey: 1923-2002. In M. Karshenas and V. M. Moghadam (eds), Social Policy in the Middle East: Economic, Political and Gender Dynamics, Basingstoke: Palgrave Macmillan, pp. ${ }_{5} 5-89$.

Bugra, A. (1998), Immoral economy of housing in Turkey, International fournal of Urban and Regional Research, 22, 2: 303-I7.

Bugra, A. and Keyder, C. (2006), Turkish welfare regime in transformation, fournal of European Social Policy, i6, 3: 21 I-28.

Chaaban, J. (2009), Youth and development in the Arab countries: the need for a different approach, Middle Eastern Studies, 45, I: 33-55.

Clark, J. (2004), Social movement theory and patron-clientelism, Comparative Political Studies, 37, 8: 94I-68.

Commission of the European Communities (2009), Turkey 2009 Progress Report, Brussels: SEC (2009) I334.

Dilik, S. (I985), Atatürk döneminde sosyal politika [Social policy in Atatürk's era], Mülkiyeliler Birliği Dergisi [Ankara University faculty of Politics Journal], 40, I: 93-IO2.

Eurofound (2003), First European Quality of Life Survey: Quality of Life in Turkey, Dublin: European Foundation for the Improvement of Living and Working Conditions.

Eurostat (2009), Labour Force Survey, Luxembourg: Office for Official Publications of the European Communities.

Ferrera, M. (I996), The 'Southern Model' of welfare in Social Europe, Journal of European Social Policy, 6, i: 17-37.

Glynos, G., Kaeding, M. and Aybars, A. I. (2008), Social Dialogue and Its Contribution to Social Cohesion in Turkey, Briefing Paper, European Parliament, Committee on Foreign Affairs, Brussels: European Parliament.

Gough, I. (1996), Social assistance in Southern Europe, South European Society and Politics, I, I: I-23.

Gough, I. (200I), Social assistance regimes: a cluster analysis, fournal of European Social Policy, II, 2: I65-70.

Grütjen, D. (2008), The Turkish welfare regime: an example of the Southern European Model? Turkish Policy Quarterly, 7, i: in I-29. 
Henry, C. M. and Springborg, R. (200I), Globalization and the Politics of Development in the Middle East, Cambridge: Cambridge University Press.

Jawad, R. (2008), Possibilities of positive social action in the Middle East: a re-reading of the history of social policy in the region, Global Social Policy, 8, 2: 267-8o.

Karshenas, M. and Moghadam, V. M. (2006), Social policy in the Middle East: introduction and overview. In M. Karshenas and V. M. Moghadam (eds), Social Policy in the Middle East: Economic, Political and Gender Dynamics, Basingstoke: Palgrave Macmillan, pp. I-3o.

Kilic, A. (2008), The gender dimension of social policy reform in Turkey: towards equal citizenship? Social Policy \&O Administration, 42, 5: 487-503.

Kuran, T. (2004), Why the Middle East is economically underdeveloped: historical mechanisms of institutional stagnation, Fournal of Economic Perspectives, I8, 3: 7I-90.

Moghadam, V. M. (2006), Gender and social policy: family law and women's economic citizenship in the Middle East. In M. Karshenas and V. M. Moghadam (eds), Social Policy in the Middle East: Economic, Political and Gender Dynamics, Basingstoke: Palgrave Macmillan, pp. 22I-53.

OECD (2009a), Employment Outlook (June), Paris: OECD.

OECD (2009b), Society at a Glance 2009: OECD Social Indicators, Paris: OECD.

Ozbudun, E. (I980), Income distribution as an issue in Turkish politics. In E. Ozbudun and A. Uksar (eds), Political Economy of Income Distribution in Turkey, New York: Holmes and Meier, pp. 55-82.

Saraceno, C. (ed.) (2002), Social Assistance Dynamics in Europe: National and Local Poverty Regimes, Bristol: Policy Press.

Schlumberger, O. (2000), The Arab Middle East and the question of democratization: some critical remarks, Democratization, 7, 4: 104-32.

Tsarouhas, D., Ertugal, E. and Aybars, A. I. (2007), Introduction: the EU-Turkey debate revisited. In D. Tsarouhas, E. Ertugal and A. I. Aybars (eds), Bridging the Real Divide: Social and Regional Policy in Turkey's EU Accession Process, Ankara: METU Press, pp. I-I6.

World Bank (2005), Turkey: Foint Poverty Assessment Report (vol. I), Human Development Sector Unit, Europe and Central Asia Region.

Yakut-Cakar, B. (2007), Turkey. In B. Deacon and P. Stubbs (eds.), Social Policy and International Interventions in South East Europe, Cheltenham: Edward Elgar, pp. I03-29. 